\title{
The Bahamas and the First Extensive Expedition (1931-1932) of the USDA to the Caribbean Islands
}

Raquel Chavarria (Dhttps://orcid.org/0000-0003-1067-2436

Florida International University

Brett Jestrow iDttps://orcid.org/0000-0003-0343-3146

Fairchild Tropical Botanic Garden

Ethan Freid (Dhttps://orcid.org/0000-0003-3890-7022

The Bahamas National Trust

Javier Francisco-Ortega ${ }^{1}$ (Dhttps://orcid.org/0000-0002-5719-7188

Florida International University

https://doi.org/10.15362/ijbs.v26i0.369

\section{Abstract}

Sponsored by Allison V. Armour and led by David Fairchild, a plant hunting expedition organized by the U.S. Department of Agriculture (USDA) targeted the Caribbean Islands and the Guianas between December 31, 1931 and April 1, 1932. Three other agricultural scientists joined this plant collecting enterprise: namely, Leonard R. Toy (from the University of Florida) and Harold Frederick and Palemon H. Dorsett (both from the USDA). Seven of the Bahamian islands were explored between December 31, 1931 and January 15, 1932 and between March 29 - April 1, 1932. This contribution focuses on the Bahamian itinerary followed during this voyage. Documents and photos housed in the U.S. National Archives and the Library and Archives of Fairchild Tropical Botanic Garden; herbarium specimens found in the U.S. National Herbarium; and David Fairchild's published accounts were the basis of our research. A total of 106 plant samples (89 species), including herbarium specimens and material for the USDA, were collected in this archipelago. Collections of an unidentified palm grown in the USDA Chapman Field Station, Miami resulted in the description of the Bahamian endemic Coccothrinax inaguensis in 1966 by Robert W. Read. The team failed to collect landraces of sea-island cotton and wild cotton species, even though that was one of the main priorities for the team. Accounts of this visit were covered by two of Nassau's newspapers: The Nassau Guardian and The Tribune.

\section{Introduction}

In 2012, The Bahamas National Trust, the University of The Bahamas (then the College of The Bahamas), Fairchild Tropical Botanic Garden, and Florida International University organized an international symposium to celebrate the 30 year anniversary of the publication "Flora of the Bahama Archipelago," by Fairchild Tropical Botanic Garden plant taxonomists Donovan and Helen Correll (1982). During this meeting, members of our team delivered an oral communication which focused on the three field trips that noted American plant explorer David Fairchild (Figure 1) made across these

\footnotetext{
${ }^{1}$ Corresponding author: ortegaj@fiu.edu
} 
islands. This presentation resulted in a contribution that was published in the proceedings of this meeting (FranciscoOrtega et al., 2014). Subsequent to this work, additional research was conducted in the U.S. National Archives at College Park, MD; the U.S. National Herbarium, Smithsonian Institution, Washington DC; and the Library and Archives of Fairchild Tropical Botanic Garden. New documents, photos, and plant specimens from the first plant hunting trip that David Fairchild (1869-1954) undertook to The Bahamas were found, and they are the subject of the study presented here.

\section{Figure 1}

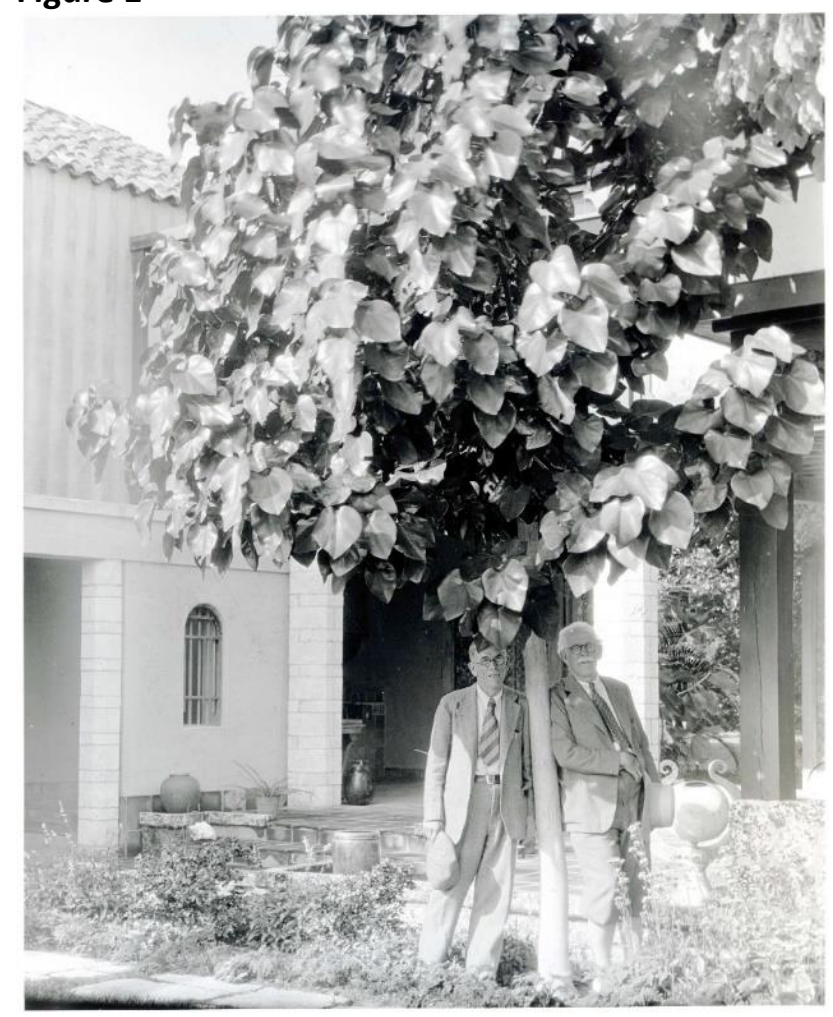

Note: Left to right, Palemon H. Dorsett and David Fairchild standing near a Hernandia sonora L., mago (Hernandiaceae) individual in the house of David Fairchild in Coconut Grove, Miami. Photo was taken in December 1931 shortly before they joined the first expedition of the USDA to the Caribbean islands. Photo credit: unknown. Courtesy of the Library and Archives of Fairchild Tropical Botanic Garden.

\section{The 1931-1932 USDA Plant Hunting Expedition to the Caribbean Islands and the Guianas}

The first official comprehensive plant hunting expedition of the U.S. Department of Agriculture (USDA) to the West Indies visited The Bahamas, the Greater and Lesser Antilles, Trinidad, Tobago and the Guianas and took place between December 1931 and April 1932 (Figure 2). This was not the first time that the USDA organized a plant germplasm survey in the Caribbean islands. Previously, David Fairchild (founder of the Section of Seed and Plant Introduction of the USDA) and his benefactor, businessman Barbour Lathrop, collected plant material in the islands of Barbados, Grenada, Jamaica, and Trinidad in January, 1899 (Fairchild, undated). However, this earlier expedition had a much more limited scope than the one that took place between 1931 and 1932.

\section{Figure 2}

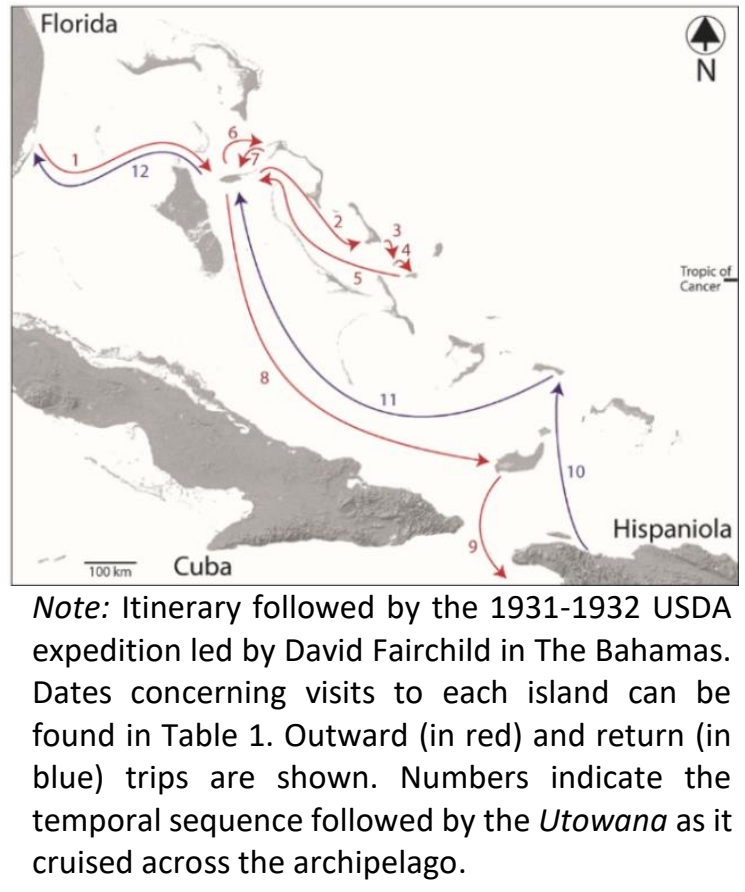

The main aim of the 1931-1932 multicountry endeavour was "to search for the wild relatives of cultivated cotton, also varieties of palms native to the regions, 
visited, as well as new, rare and valuable plants deemed worthy of introduction and trial in the United States, and its possessions" (Dorsett, 1936, p. 1). Within these goals, collecting "sea-island cotton" was one of the main objectives of this enterprise (Dorsett, 1936, p. 2; Fairchild, 1934). This is a crop that was developed through hybridizations between Gossypium barbadense L. and $G$. hirsutum L. (Stephens, 1976). It was relatively important in the West Indies and in the southeastern United States because of its high quality, long, silky fibres (Stephens, 1976; Porcher \& Fick, 2005). Geographically, the term "sea-island" refers to the many small barrier and tidal islands that are scattered across coastal areas of northeastern Florida, Georgia and a great portion of South Carolina. Traditionally, it has been considered that sea-island cotton was originally grown in the southeastern United States from seeds that came from the island of Anguilla, Lesser Antilles (Moore, 1934) or from The Bahamas or Barbados (Dorsett 1936, p. 2). Between the 18th and the middle 19th century, cotton was a significant cash crop of The Bahamas (Eneas, 2013, pp. 12, 160), and this was a primary reason these islands were targeted during this expedition, as it was believed that they might still have remnants of this crop. Unfortunately, this target was not achieved, and the expedition returned to the United States without any major landraces or collections of sea-island cotton, neither from The Bahamas nor from any other Caribbean island (Dorsett, 1936, p. 695; Fairchild, 1934).

Notable expedition members included David Fairchild as the expedition leader, his daughter Nancy Fairchild (1912-1976), and his wife Marian Fairchild (1880-1962). The agricultural scientists were Leonard R. Toy (1900-1973, Figure 3), a horticulturist who worked at the University of Florida State Experimental Station at Homestead, Miami-
Dade County; Harold Frederick Loomis (1896-1976, Figure 2), an entomologist and botanist from the Miami USDA Research Station at Chapman Field and the noted USDA botanist and plant collector, Palemon H. Dorsett (1862-1943, Figure 1), two additional members were Jordan C. Mott (1857-1932) and Allison Armour (18631941). The latter was a businessman from Chicago who was one of the main supporters of David Fairchild's plant collecting enterprises (Francisco-Ortega et al., 2012). Regarding Jordan Mott, he was also a wealthy businessman from New York and a friend of Armour.

The voyage took place on board Utowana, a research yacht that was owned by Armour, that between 1925 and 1933 was used extensively by David Fairchild for his USDA expeditions to the 'New' and 'Old World' (Fairchild, 1930; Francisco-Ortega et al., 2012, 2014, 2018, 2019).

The party departed from Miami on December 30, 1931 and returned to Miami on April 2, 1932. Plant material was collected across all the visited islands and continental areas (Dorsett, 1936). Further details pertinent to the work that was conducted in Haiti and to the full itinerary can be found in FranciscoOrtega et al. (2018, 2019). As a result of this expedition, David Fairchild (1934) wrote a popular article with an overview of this plant exploration initiative shortly after his return to the United States. The Bahamas was visited between December 31, 1932 and January 15,1932 , during the onward trip to the Guianas, and between March 29, 1932 and April 1, 1932 during the return voyage to Miami (Table 1, Figure 4). A total of seven islands were explored: Cat Island, Conception Island, Great Inagua, Eleuthera, New Providence, Mayaguana, and Rum Cay. The Bahama itinerary was influenced by the death of one of the expedition members, Jordan Mott, who passed away on Rum Cay on January 7, 1932 when Utowana was 


\section{Figure 3}

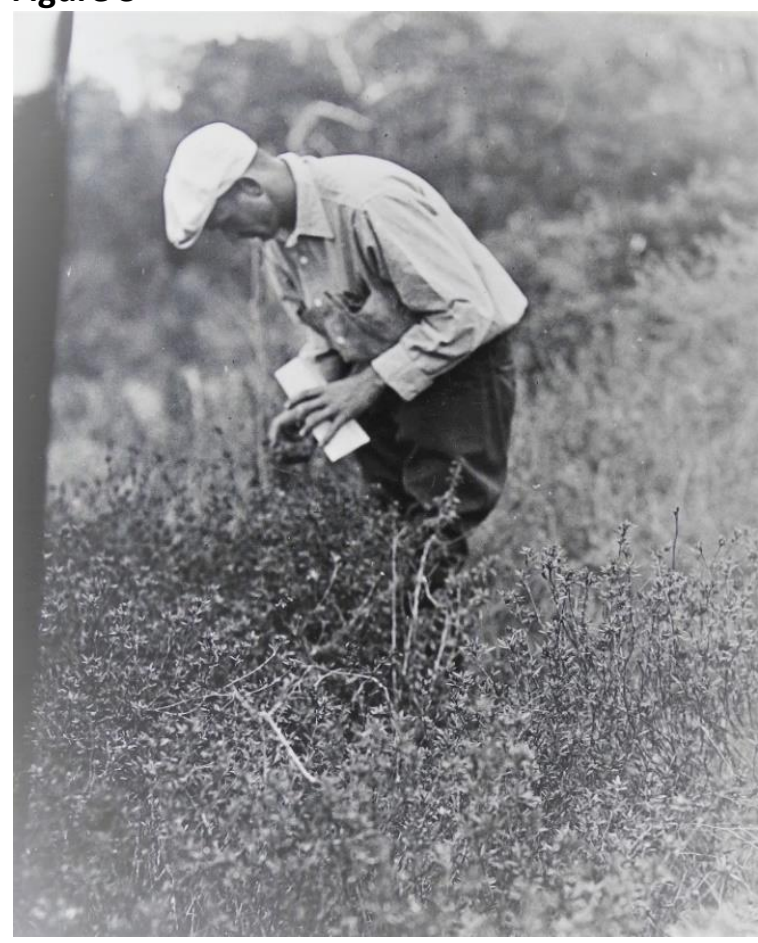

Note: Leonard R. Toy collecting seeds of the legume Stylosanthes hamata (L.) Taubert (cheesytoes) in Great Inagua, January 15, 1932. This material was specifically collected for the USDA fodder specialist Roland Mckee. Photo credit: Palemon H. Dorsett (1936, p. 167, negative 57741). Courtesy of the U.S. National Archives at College Park, MD.

\section{Figure 4}

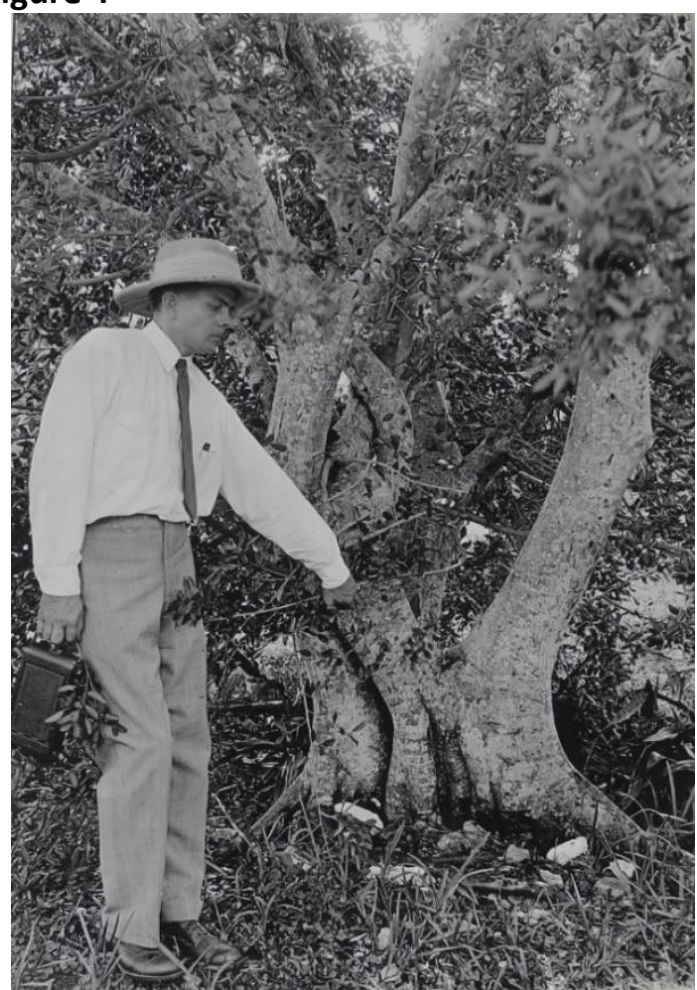

Note: Harold Loomis standing near an individual of Ficus americana in the garden of Arthur C. Langlois (currently The Retreat Gardens, Bahamas National Trust), Nassau, January 1, 1932. USDA accession number 95691. Photo credit: Palemon H. Dorsett (1936, p. 79, negative 57644). Courtesy of the U.S. National Archives at College Park, MD.

\section{Table 1}

Dates for the itinerary followed by the 1931-1932 USDA expedition led by David Fairchild in The Bahamas. Map of itinerary can be seen in Figure 2 .

\begin{tabular}{lll}
\hline Island & Length of visit & Notes \\
\hline New & December 31, 1931 - January 3, & Outbound trip. Utowana arrived from Miami \\
Providence & 1932 & Outbound trip. \\
Cat Island & January 4 - January 5, 1932 & Outbound trip. \\
Conception & January 5 - January 6, 1932 & Outbound trip. \\
Rum Cay & January 6 - January 7, 1932 & Outbound trip. \\
New & January 8 - January 10,1932 & Outbound trip. \\
Providence & January 10 - January 11, 1932 & Outbound trip. \\
Eleuthera & Jew & Outbound trip. Utowana left for Beata Island (Dominican \\
Providence & January 12, 1932 & Republic) \\
Great Inagua & January 14 - January 15, 1932 \\
Mayaguana & March 29, 1932 & Return trip. Utowana arrived from Cap Haitien (Haiti) \\
New & March 31 - April 1, 1932 & Return trip. Utowana left for Miami \\
\hline
\end{tabular}


heading to the Antilles (Dorsett, 1936, pp. 113-114). Because of this tragic loss, the travel plans needed to be changed, and the expedition members headed back to Nassau to make funeral arrangements. This also meant that the party stayed longer than expected in The Bahamas and during this stay, they visited the island of Eleuthera.

\section{The Archive and Herbarium Research}

During our visit to the United States National Archives, an extensive two-volume report (902 pages and 684 photos) that expedition member Palemon H. Dorsett prepared for the expedition was located (Dorsett, 1936). Interestingly, this official USDA document also includes the travelogue that he wrote during this trip. One-hundred thirteen pages of this report, including 122 photos, are devoted to The Bahamas (Dorsett, 1936, pp. 67-171 for the onward trip and pp. 670-677 for the return trip). An annotated copy of the Bahamian portion of this document is available as an online supplementary Appendix 1 (https://archive.org/details/ chavarria-et-al.-d.-fairchild-in-the-bahamasintl.-j.-baha.-stud.-appendix-1).

Herbarium specimens from The Bahamas made during this expedition were located in the U.S. National Herbarium (Smithsonian National Museum of Natural History, Washington, DC). We found 50 specimens (including one set of duplicates for Galactia striata) for 49 species. Images for all of these specimens have been posted online on the website of this herbarium (https://collections.nmnh.si.edu/search/botan $\mathrm{y} /$ ), and they can be downloaded through internet hyperlinks posted in online supplementary Appendix 2 (https://archive.org/details/chavarria-et-al.d.-fairchild-in-the-bahamas-intl.-j.-baha.stud.-appendix-2).

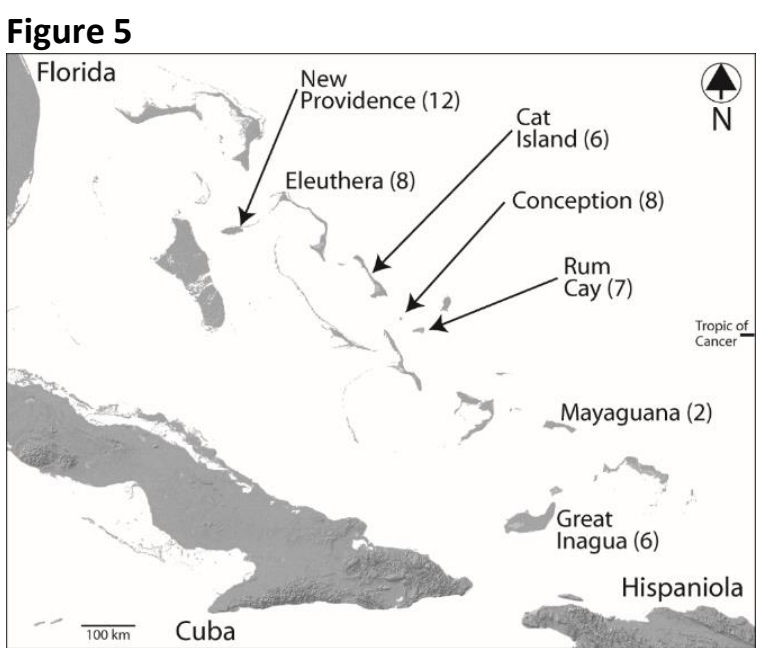

Note: Number of herbarium collections made during the 1931-1932 USDA expedition led by David Fairchild in The Bahamas.

The Library and Archives of Fairchild Tropical Botanic Garden house 88 of the photographs made in The Bahamas during this trip. These photos are either mounted on scrapbooks or available as negatives. Seventy-four of these photos are also found in Dorsett's report; in total 136 photographs were taken by Dorsett or Fairchild in The Bahamas. An inventory of these images with brief descriptions of their content is presented in online supplementary Appendix 3 (https://archive.org/details/chavarria-et-al.d.-fairchild-in-the-bahamas-intl.-j.-baha.stud.-appendix-3).

The archives of this botanic garden also house David Fairchild's collection books. These books have both details pertinent to the actual collected material and post-expedition notes, with information on the status of the collected accessions as they were introduced in the USDA stations of Chapman Field, Miami (abbreviated as "C.F." in the collection books) and Washington, DC (abbreviated as "Det. House D.C."). Collection books 1, 2, 9 and 14 list a total of 59 plant samples as they were sampled in The Bahamas during this expedition. These collection books were scanned, and they are posted in online supplementary Appendix 2 
(https://archive.org/details/chavarria-et-al.d.-fairchild-in-the-bahamas-intl.-j.-baha.stud.-appendix-2). Taxonomy mostly follows Acevedo-Rodríguez \& Strong (2012).

\section{Expedition Outcomes ${ }^{2}$}

The 1931-1932 USDA Plant Hunting Expedition to the Caribbean Islands and the Guianas was the first one organized by the USDA that collected plant material in The Bahamas. It resulted in plant collections and botanical accounts that provide a good perspective concerning agricultural development in these islands during the 1930s. Herbarium specimens (Figure 5) and samples for USDA (Figure 6) were made, and photos were also taken (Figure 7), in the seven islands that were visited during this expedition.

\section{Figure 6}

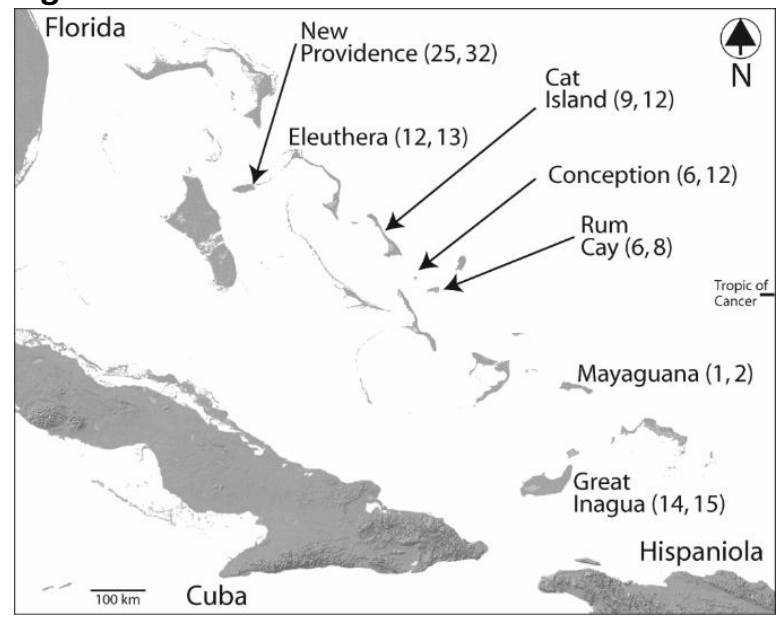

Note: Number of plant accessions collected during the 1931-1932 USDA expedition led by David Fairchild in The Bahamas. First number refers to accessions that were registered in the USDA germplasm system after the expedition finished, based on Ryerson (1933, 1934). Second number represents accessions that were collected during the expedition, based on Dorsett's (1936) report and on Fairchild's collection books housed in the Library and Archives of Fairchild Tropical Botanic Garden.

\footnotetext{
2 Throughout the text we refer to relevant page numbers of Dorsett's (1936) report in parentheses.
}

The visit of Fairchild and his colleagues received coverage in two Nassau newspapers (i.e., The Nassau Guardian and The Tribune), as they reported details pertinent to the arrival of the expedition to The Bahamas ("The 'Utowana' in the Harbour," 1932). Furthermore, the newspapers made reference to the accounts that Fairchild and his colleagues did to bud rot as a major disease that was severely affecting coconut palms ("Menace to Coconut Palms," 1932; "Inspection of Coconut Palms," 1932), and also reported on the sudden death of expedition member Jordan C. Mott in Rum Cay ("Man Dies on Yacht off Rum Cay," 1932; "Memorial Service to Mr. Jordon Mott," 1932).

\section{Figure 7}

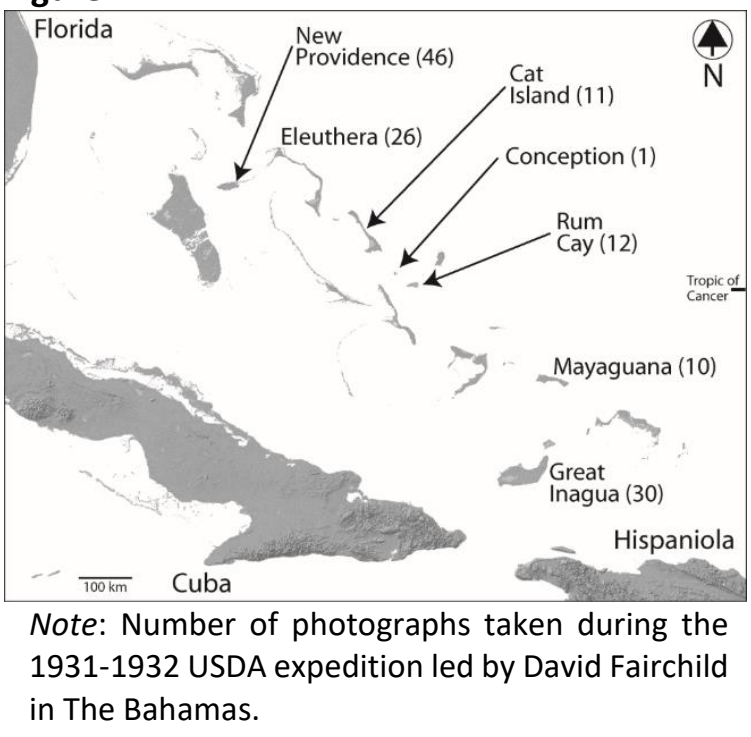

\section{Agricultural and Ethnobotanical Accounts}

Dorsett's report has insights regarding the use of plants in this archipelago and the wellknown challenges to agriculture in The Bahamas during the 20th century (Eneas, 2013). The USDA team encountered relatively rudimentary agriculture systems, in 
which the clearing of crown land (i.e., government land available for public use) was a common practice (pp. 141, 146-147; Figure 8).

\section{Figure 8}

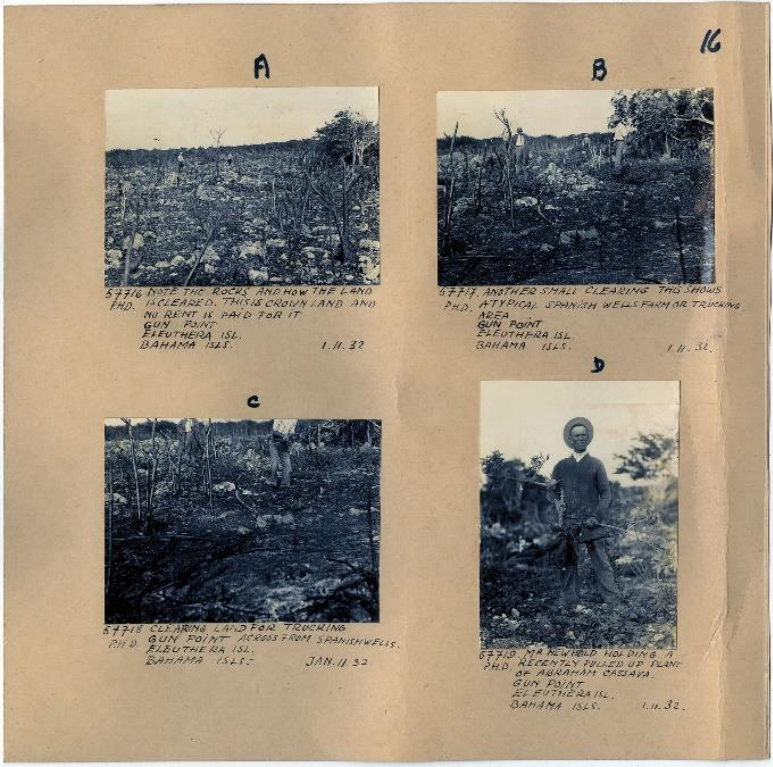

Note: Photographs mounted on one of the scrapbooks (p. 16 of scrapbook 14) showing crown-land being cleared for agriculture in Eleuthera, January 11, 1932. David Fairchild is standing in the background of image B. Photo credit: Palemon H. Dorsett (1936, pp. 146-148, negatives 57716-57719). Courtesy of the Library and Archives of Fairchild Tropical Botanic Garden.

This was clearly stated by Dorsett (1936) when describing Eleuthera's fields: "the methods and practices of the handling of both the land and the crops which are being grown are extremely primitive and shiftless" (p.141). Dorsett's (1936) account has references to historical failures or the dire situation of crops such as sisal (pp. 91, 104), coconut (pp. 72, 80), cascarilla (p. 91), pineapple (p. 91), and citrus (pp. 135-136, 138-139). It appears that during Fairchild's visit, tomato production took over some of these other crops (p. 91) as also reported by Eneas (2013, p. 14). Concerning cotton, Dorsett (1936) only provided two brief accounts about this crop in The Bahamas, and these accounts refer to collections of a "hybrid" (p. 101) and of plants "which escaped from cultivation" (p. 105) on Conception Island and Rum Cay. Therefore, samples of wild cotton were not collected during their stay in the archipelago. Records on the local use of plants were also mentioned by Dorsett. Bananas were found mostly grown in "pot holes in coral lime stone" ( $p$. 97; Figure 9); seedless breadfruit were reported for Nassau (pp. 86, 95, 128-129); mahogany was used as construction material in houses (p. 139), and the Caribbean endemic cascarilla was still locally cultivated and used because of the alleged medicinal properties of its bark (pp. 95-96).

Dorsett (1936) also highlighted the relevance of the fruit of the sapodilla tree, (pp. 70, 98$99,104)$ as it was described as "one of their most abundant and important fruits" (p. 70). During the expedition, Fairchild particularly noticed the poor effect that jumbay beans had on the hair of domestic animals when they were fed this legume (pp. 73-74, 87-88, 131). Three photos showing mules with little hair are presented in this document (Figure 11). A major fungal soil disease known as bud rot or bud disease that was depleting coconut trees was also reported (pp. 72, 80). Likewise, observations were made regarding the detrimental effect that the citrus blackfly (Aleurocanthus woglumi Ashby, Hemiptera) and citrus whitefly [Dialeurodes citri (Ashmead), Hemiptera] had on the citrus industry across the archipelago (pp. 135-136, 138-139). Among the food crops, it appears that pigeon peas represented one of the most important staples (pp. 70, 91, 120-122) and five photos of grains of this legume being sold in the Nassau market can be found in this report (Figure 10). 


\section{Figure 9}

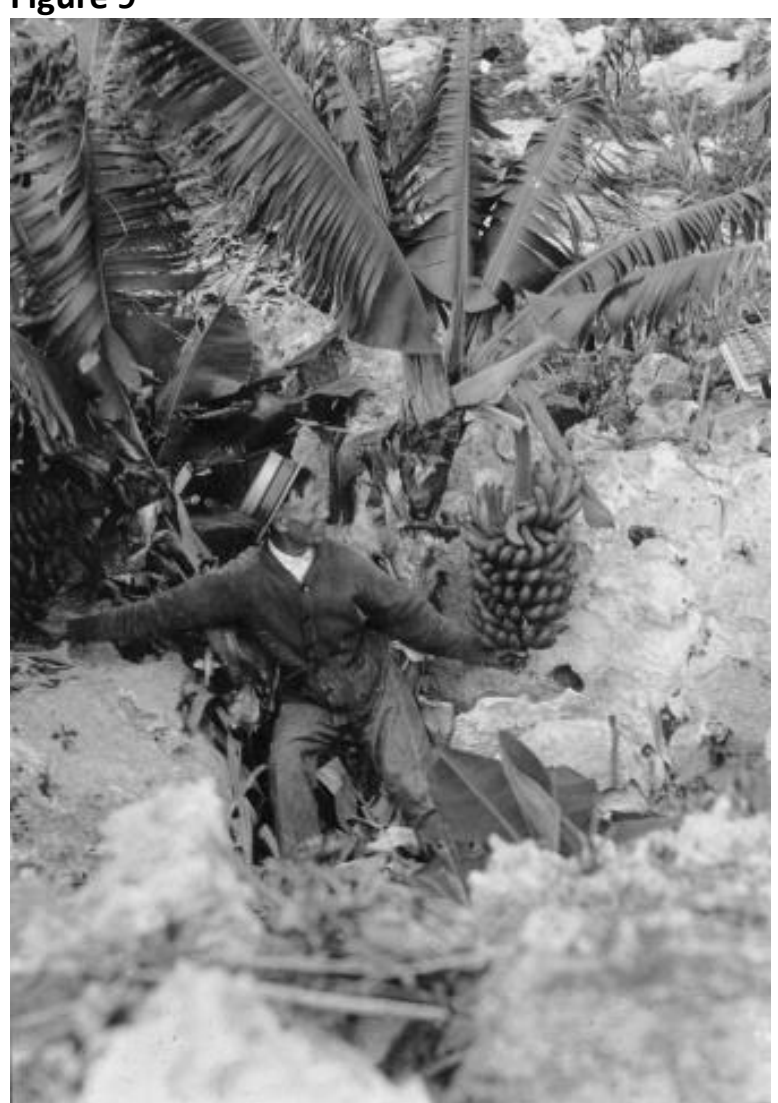

Note: Banana plants growing inside potholes in Eleuthera, January 11, 1932. USDA accession number 95691. Photo credit: Palemon H. Dorsett (1936, p. 149, negative 57771). Courtesy of the Library and Archives of Fairchild Tropical Botanic Garden.

\section{Figure 10}

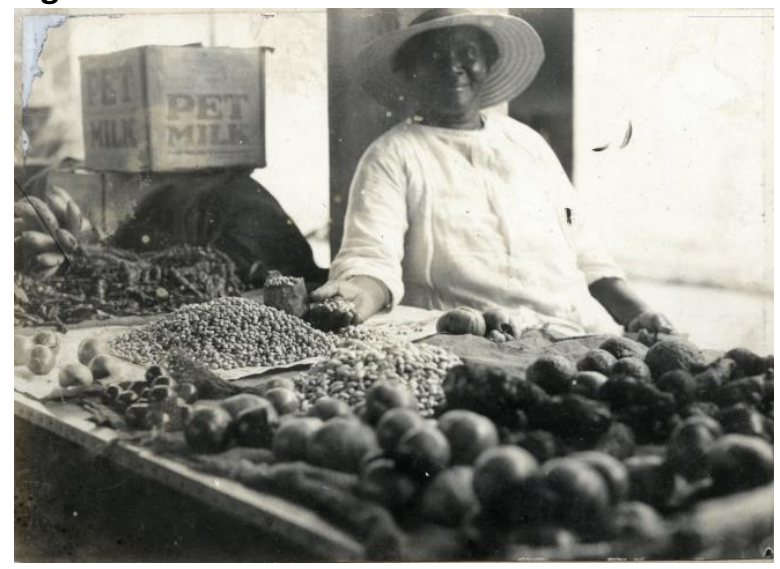

Note: Pigeon peas (Cajanus cajan (L.) Millsp.) being sold at the market in Nassau, January 9, 1932. Photo credit: Palemon H. Dorsett (1936, p. 122, negative 57681). Courtesy of the Library and Archives of Fairchild Tropical Botanic Garden.

\section{Figure 11}

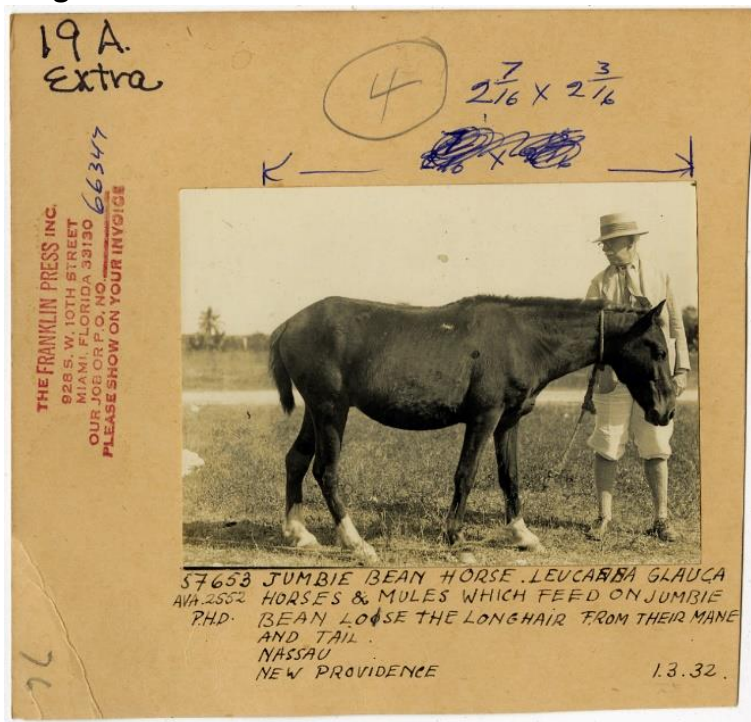

Note: Photo mounted on scrap book (number 19A. Extra) showing David Fairchild standing near a horse that has shed its hair because it was fed with jumbay beans (Leucaena leucocephala), Nassau, January 1, 1932. Photo credit: Palemon H. Dorsett (1936, p. 88, negative 57653). Courtesy of the Library and Archives of Fairchild Tropical Botanic Garden.

\section{Plant Collections}

Previous research studies have shown that, as a plant explorer, David Fairchild had a broad sampling strategy and usually made collections in private and public gardens. He also procured plant material from agriculture research stations, small orchards, plantations, natural habitats, and markets (Korber et al., 2016; Rose et al., 2017). The Bahamas was not an exception, and the records found both in Dorsett's report and in the collection books show the wide collection scope that he had in The Bahamas. For instance, a total of eight samples were collected in the garden of Mrs. Edward George in Nassau (pp. 118-120, 124131) and there are extensive illustrated accounts on the local market of Nassau in Dorsett's travelogue (pp. 68, 117-118, 120$124,133)$. Several private gardens were visited including "The Retreat" at Nassau, currently managed by The Bahamas National Trust, but during Fairchild's visit, this site 
was owned by palm expert Arthur C. Langlois (pp. 78-79; Figure 4). Other gardens from Nassau mentioned or photographed by Dorsett (1936) were the ones that belonged to Charles S. Dolley (p. 69), to Mr and Mrs. R. H. Curry (p. 75), and to the Bahamas General Hospital (pp. 76-77). It appears that in most of the visited islands, the expedition members had great interactions with local residents. In New Providence they received assistance from Dr. Albury (pp. 68-69; the Alburys also hosted expedition members in Eleuthera, pp. 135, 137) and D. Lawrence (p. 86); and they also met with the United States Consul Fred D. Fisher (p. 87). Dorsett's (1936) records note other locals from whom they received ample support: Mr. Brown, agricultural instructor and horticulturist of Cat Island (pp. 91, 95-97); vessel Captain Albert Pinder ( $\mathrm{p}$. 133) from Eleuthera (p. 133); the Dorsetts from Conception (p. 103) and Mr. Darville from Great Inagua (p. 159). We have been unable to find biographical details for the vast majority of these people with the exception of Charles S. Dolley (Gifford, 1947; Fairchild, 1948) and Arthur C. Langlois (Mosely Latham, 2008).

A total of 106 plant collections, for 89 species, were made in The Bahamas (Appendix 2). Only one of these samples (collection 2607) has an uncertain origin, as it is not clear if it was collected in The Bahamas or from Beata Island, Dominican Republic. There are also uncertainties regarding the actual provenance of eight samples; they were reported as collected in The Bahamas but without any particular island or locality details. Cotton was the crop most extensively sampled, with nine samples. Twenty-one of the 106 collections were only for herbarium specimens; therefore, they did not include samples for the USDA. Twenty of the samples were of cultivated species, eight non-cultivated introduced species, 38 Bahamian natives, seven Caribbean Island endemics and three species endemic to the
Bahamas (Appendix 3). Thirty-six of the collected samples were not registered in Fairchild's collection books. Fairchild assigned them accession numbers with a low value $(<81)$. It is unclear why he decided to keep these samples under a different numeric system. Based on information recorded in Fairchild's collection books, 17 of the collected accessions were already in cultivation in 1932 either in Washington, DC (six samples) or in Miami.

Palms were one of the main objectives of this expedition, and ten accessions were obtained for them; eight of these samples were of cultivated species, and the rest were collected in the wild. There was a particular interest in obtaining material of Pseudophoenix sargentii, buccaneer palm or hog palm ( $\mathrm{p}$. 105), a species endemic to the upper Florida Keys (Elliott Key, in Biscayne National Park) and the Caribbean Islands. In Dorsett's report (1936), Fairchild indicated that this palm was used to feed hogs in Little San Salvador Island and in Cat Island (pp. 99-100). The only sample that was collected for this species came from Mrs. George's garden. The samples of Coccothrinax sp. collected in Great Inagua (Figure 12) resulted in the most significant taxonomic contribution of this expedition. Individuals of this species were subsequently cultivated in the USDA station of Chapman Field, Miami, and they were the basis for the description of The Bahamian endemic $C$. inaguensis (Figure 13) by Read (1966).

\section{Discussion and Concluding Remarks}

By the time of the arrival of this USDA expedition to The Bahamas, there were no cotton plantations left in The Bahamas (Eneas, 2013, p. 160), and this could explain why only nine samples of this crop were collected. It is unknown to what extent these old Bahamian cultivars were the same ones found in the lowland and coastal areas of northern Florida, Georgia and South 
Carolina; however, it has been claimed that by the late 18th century, the crop was introduced in The Bahamas by settlers from the southern United States (Porcher \& Fick, 2005, pp.78-79). By 1838, cotton was already in decline, mostly because of the abolition of slavery and poor agricultural practices (Eneas, 2013, p. 160). Populations of wild cotton occur in The Bahamas, and according to Correll \& Correll (1982, pp. 926-927), they belong to Gossypium hirsutus var. punctatum. Plants of this variety are mostly found along roadsides and waste areas. Perhaps because this Bahamian wild cotton rarely grows in natural habitats and can be regarded as a weed, it was not collected by the USDA team.

\section{Figure 12}

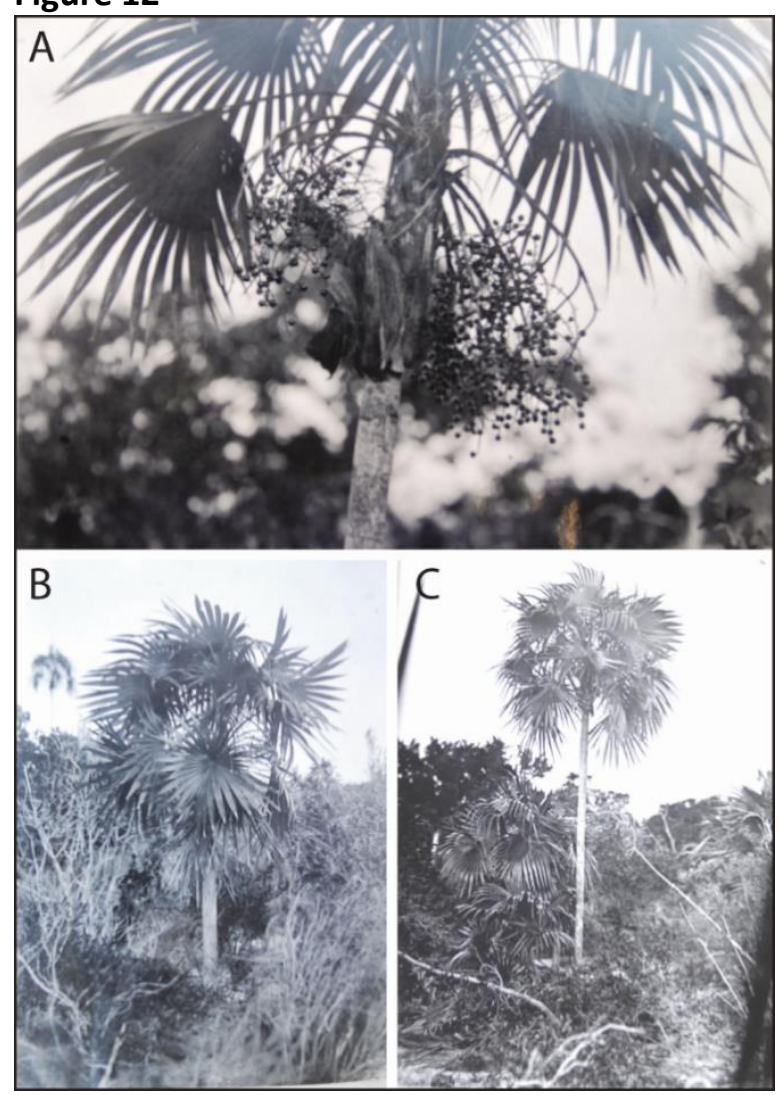

Note: Coccothrinax inaguensis in Great Inagua, January 15, 1932. Photo credit: Palemon $\mathrm{H}$. Dorsett (1936, p. 165, negative 57736 for image A; negative 57737 for image B; 170, negative 57746 for image C). Courtesy of the U.S. National Archives at College Park, MD.
Palm trees were another objective of this expedition; among the six genera with native species in The Bahamas, four of them were not sampled: Acoelorraphe wrightii (Peurotis palm, found in Andros and New Providence), Leucothrinax morrisii (thatch-palm, found throughout the archipelago), Roystonea regia (royal palm, found in Little Inagua), and Sabal palmetto (hat palmetto, found throughout the archipelago). Two of them, $L$. morrisii and $S$. palmetto, are relatively common in Florida, and this could explain why they were not sampled during this expedition. Roystonea regia is a species that, in the Bahamian archipelago, is found only in Little Inagua, an island that was not surveyed. Acoelorraphe wrightii reaches New Providence, where it is extremely rare.

\section{Figure 13}

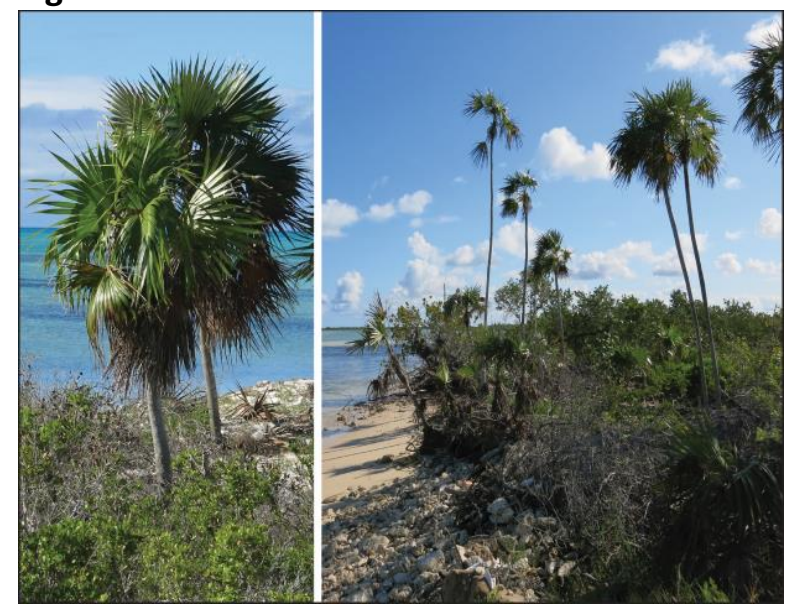

Note: Coccothrinax inaguensis individuals in habitat in Great Inagua. Photo credit: Brett Jestrow.

Unlike other islands of the West Indies under British administration, The Bahamas did not have any botanical gardens during colonial rule. Indeed, the first botanic garden in the archipelago was established in Nassau on July 10, 1973, the same day of The Bahamas' independence. It is worth mentioning that during this USDA expedition, Fairchild collected plant material in botanic gardens of the Lesser Antilles, Trinidad and the Guianas. Because some of these botanic gardens were established in the 18th century, 
it was expected that they had some of the earliest introductions of tropical plants in the region.

It is clear that the expedition did not visit some of the areas with relevant species of palms, and it sampled cotton accessions that were of limited breeding interest. Despite these drawbacks, David Fairchild and his colleagues collected local cultivars of other crops, took many photographs across the archipelago, and provided accounts of historical importance regarding the status of agriculture and daily life of The Bahamas in the 1930s.

\section{Acknowledgements}

This is contribution 373 from the Tropical Biology Program of Florida International University (FIU). We dedicate this paper to H. Eshbaugh in recognition of his research and educational contributions to Bahamian flora. Raquel Chavarria framed this research within the Global Learning Medallion program of FIU's Global Learning Initiative. Carol Dietrick, J. Dietrick, M. Swan, and L. Bennett provided invaluable assistance during the archival research. Visits made by

\section{References}

Acevedo-Rodríguez, P. \& Strong, M. T. (2012). Catalogue of seed plants of the West Indies. Smithsonian Contributions to Botany, 98, 1-1192. https://doi.org/10.5479/si.0081024X.98.1

Correll, D. S. \& Correll, H. B. (1982). Flora of the Bahama archipelago. Gantner Verlag.

Dorsett, P. H. (1936). Allison V. Armour Agricultural Expedition for the U.S. Department of Agriculture with the Yacht Utowana, visiting islands of the British West Indies and British and Dutch Guiana, Nov. 1931-Apr. 1932. Expedition
JFO to the U.S. National Archives were sponsored by the following FIU units: the Kimberly Green Latin American and Caribbean Center and the International Center for Tropical Plant Conservation. The Smithsonian's National Museum of Natural History provided additional support to these visits. Meghann Toner and I. Lin helped to locate relevant specimens in the U.S. National Herbarium. We are grateful to those colleagues who kindly helped us with taxonomic queries concerning Bahamian flora: (M. Vincent), Bucida (P. Acevedo), Quadrella (X. Cornejo), Encyclia (J. Ackerman), Ficus (L. Cardoso Pederneiras), Iresine (I. Sánchez del Pino), Passiflora (T.E. Boza Espinoza), Phaseoleae (A. Delgado Salinas), Poaceae (F. Zuloaga), Tabernaemontana (F. Morales), Talinum (D. Goldman), and Zephyranthes (A. Meerow). Paul C. Aranha and J. Lawlor (The Bahamas Historical Society) provided insights regarding the history of The Bahamas. Paul Kendra (USDA, Miami) helped with information on citrus pests in The Bahamas.

Reports of the Office of Foreign Seed and Plant Introduction of the Department of Agriculture, 1900-1938 (Vol. 74-75). U.S. National Archives, College Park, MD, United States.

Eneas, G. (2013). Agriculture in The Bahamas: Historical development. (2nd ed.). Media Enterprises.

Fairchild, D. (undated). List of inventory numbers of Section of Seed and Plant Introduction which refers to seeds and plants secured by Lathrop and Fairchild. Unpublished report. Archives of Fairchild Tropical Botanic Garden, Miami, FL, 
United States.

Fairchild, D. (1930). Exploring for plants:

From notes of the Allison Vincent Armour expeditions for the United States

Department of Agriculture, 1925, 1926, and 1927. Charles Scribner's Sons.

Fairchild, D. (1934). Hunting useful plants in the Caribbean. The National Geographic Magazine, 66(6), 705-737. https://www.saba-news.com/wpcontent/uploads/2015/09/NationalGeographic-Dec-1934.pdf

Fairchild, D. (1948). Dr. Charles Sumner Dolley. The Fairchild Tropical Garden Bulletin, 4(1), 2. http://archive.fairchildgarden.org/portals/0 /docs/CTPC/Javier/David_Fairchild_Paper s/412_Dr_Charles_sumner_Dolley.pdf

Francisco-Ortega, J., Korber, N, Swan, M., Mosely, J., Freid, E. \& Jestrow, B. (2014). Plant hunting expeditions of David Fairchild to The Bahamas. Botanical Review, 80, 164-183. https://doi.org/ 10.1007/s12229-014-9139-x

Francisco-Ortega, J., Santamaria, Y., Jestrow, B. \& Swan, M. (2019). David Fairchild in the Caribbean: Five months (1931-1932) of plant hunting on board Utowana. The Tropical Garden, 74(1), 54-57. http://archive.fairchildgarden.org/Portals/0 /TTG-Utowana-in-the\%20CaribbeanDorsett-Travelogue.pdf

Francisco-Ortega, J., Santos-Guerra, A., Mosely, J. L., Korber, N. \& Swan, M. (2012). David Fairchild expeditions to the Canary Islands. Plant collections and research outcomes. Brittonia, 64, 421-437. https://doi.org/10.1007/s12228-012-9257$\mathrm{X}$

Francisco-Ortega, J., Swan, M., Cinea, W., Beaussejour, N., Latham, J. M. \& Jestrow, B. (2018). David Fairchild's plant hunting expeditions in Haiti. Huntia, 17, 5-35. http://www.huntbotanical.org/admin/uploa ds/02-hibd-huntia-17-1-pp5-35.pdf

Gifford, J. C. (1947). Charles Sumner Dolley. The Fairchild Tropical Garden Bulletin, 2(6), 3, 7.

Inspection of coconut palms: Trees affected by fungus disease, not bud rot. (1932, January 13). The Nassau Guardian. https://www.fairchildgarden.org/Portals/0/ Anonymous\%201932.jpg

Korber, N., Nassar, J. M., Mosely, J., Jestrow, B., Lewis, C. \& Francisco-Ortega, J. (2016). The last plant hunting expedition of David Fairchild: Venezuela and Colombia (March-April 1948). Brittonia, 68, 170-186. https://doi.org/ $10.1007 / \mathrm{s} 12228-015-9406-0$

Man dies on yacht off Rum Cay. (1932, January 8). The Tribune. https://archive.org/details/chavarria-et-al.d.-fairchild-in-the-bahamas-intl.-j.-baha.stud.-nassau-newspaper

Memorial service to Mr. Jordon Mott. (1932, January 13). The Nassau Guardian. https://archive.org/details/chavarria-et-al.d.-fairchild-in-the-bahamas-intl.-j.-baha.stud.-nassau-newspaper

Menace to coconut palms: Warning by visiting horticulturists. (1932, January 6). The Nassau Guardian. https://archive.org/details/chavarria-et-al.d.-fairchild-in-the-bahamas-intl.-j.-baha.stud.-nassau-newspaper

Moore, W. R. (1934). The golden isles of Guale. The National Geographic Magazine, 65, 235-264.

Mosely Latham, J. (2008). The Langlois' legacy in palms. The Tropical Garden, 63(2), 44-45.

Porcher, R. D. \& Fick, S. (2005). The story of sea island cotton. Wyrick and Company.

Read, R. W. (1966). Coccothrinax inaguensis- 
A new species from the Bahamas.

Principes, 10, 29-35. http://media.e-

taxonomy.eu/palmae/protologe/palm_tc_4

4415_P.pdf

Rose, P. E., Campbell, K. St. E., Commock, T., Korber, N., Latham, J. M., Swan, M. \& Jestrow, B. (2017). David Fairchild's expedition to Jamaica on board Utowana. Journal of the Torrey Botanical Society, 144, 139-152.

https://doi.org/10.3159/TORREY-D-1600010

Ryerson, K. A. (1933). Plant material introduced by the Division of Foreign Plant Introduction, Bureau of Plant Industry, January 1 to March 31, 1932 (nos. 95552-98256). United States Department of Agriculture. Inventory, 110, 1-96. https://www.ars- grin.gov/npgs/pi_books/scans/pi110.pdf

Ryerson, K. A. (1934). Plant material introduced by the Division of Foreign Plant Introduction, Bureau of Plant Industry, April 1 to June 30, 1932 (nos. 98257-100467). United States Department of Agriculture. Inventory, 111, 1-93. https://www.arsgrin.gov/npgs/pi_books/scans/pi111.pdf

Stephens, S. G. (1976). The origin of Sea Island cotton. Agricultural History, 50(2), 391-399.

https://www.jstor.org/stable/3741338

The 'Utowana' in the harbour. (1932, January 2). The Nassau Guardian. https://archive.org/details/chavarria-et-al.d.-fairchild-in-the-bahamas-intl.-j.-baha.stud.-nassau-newspaper 